\title{
多段吸着式冷凍機における吸着剤量分配比の影響*
}

\author{
井上 哲*1, 井上誠 司*1, 小林 敬 幸*2

\section{The Effect of a System Changing the Weight Ratio of an Adsorbent of Multistage Adsorption Refrigerator}

\author{
Satoshi INOUE*3, Seiji INOUE and Noriyuki KOBAYASHI \\ ${ }^{* 3}$ DENSO CORPORATION R \& D Dept. 1 , \\ 500-1 Minamiyama Komenogi-cho, Nisshin-shi, Aichi, 446-0111 Japan
}

\begin{abstract}
The adsorption refrigerator makes waste heat a useful energy source. Therefore, it is effective for improvement in energy efficiency. We proposed a multistage adsorption system, which makes it possible to bring out useful performance even under the high ambient temperature. In the previous report, the authors decided the optimal number of stages by the simulation and the experiment. In this paper, the effect of a performance of a system changing the weight ratio of the silica-gel was studied by the simulation. It was clarified that the performance was improved by $4 \%$ with increasing the ratio of adsorption weight on the low temperature stage.
\end{abstract}

Key Words : Waste Heat Recovery, Adsorption Refrigerator, Adsorbent, Multistage

吸着式冷凍機はエネルギ一効率の向上に有効な手 段の一つである.

吸着式冷凍機の汎用性を高めるためには低温排熱 や, 高温の冷却水で作動することが必要と考えられる. 低温排熱の利用は Alam K. C. A. 浜本 ${ }^{(1)(2)} ら$ らっつて, 多段で脱着を促進した検討がなされている. 著者らは 吸着時の高温の冷却水での作動に主眼を置き, 外気温 度が $40^{\circ} \mathrm{C}$ を超える条件下でも性能を発揮できるシリ カゲルー水系の多段吸着システムを提案し, 既報 で理論計算と実験から吸着器の段数を 8 段と決定した.

本報では吸着剤の分配比を変更することによる性能向 上の可能性をシミュレーションにて検討した.

\section{1. 解析モデル}

図 1 に解析モデルを示す. 吸着器は内部の仕切りで 8 分割されており, 各部屋が独立して気密を保持して いる. 室内熱交換器に近いほうから 1 段, 2

段, ・・8 段とする.

吸着剤は 8 段の総量で $1 \mathrm{~kg}$ 充填されている. 解析方法は既報 ${ }^{(4)}$ を参照されたい.

\footnotetext{
* 原稿受付 2007 年 12 月 10 日.

*1 正員, (株) デンソー(桥 470-0111 日進市米野木町南山 5001).

*2 正員, 名古屋大学エコトピア科学研究所 (邑 464-8603 名古 屋市千種区不老町).

E-mail : satoshi_inoue@denso.co.jp
}

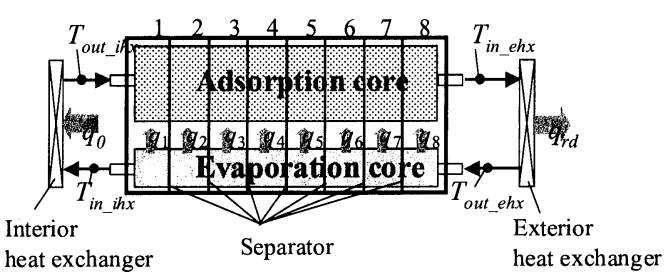

Fig. 1 Simulation model

表 1 は吸着剤の重量分配比である. 分配比に応じて 熱交換器の重量, 面積も同比率で変化させている.

Table 1 Adsorbent weight ratio

\begin{tabular}{|c|c|c|c|c|c|c|c|c|}
\hline & \multicolumn{1}{|c|}{ Low temp. stage } & \multicolumn{4}{|c|}{ High temp. stage } \\
\hline Stage No. & 1 & 2 & 3 & 4 & 5 & 6 & 7 & 8 \\
\hline A & 1 & 1 & 1 & 1 & 1 & 1 & 1 & 1 \\
\hline B & 0.7 & 0.8 & 0.9 & 1 & 1 & 1.1 & 1.2 & 1.3 \\
\hline C & 1.3 & 1.2 & 1.1 & 1 & 1 & 0.9 & 0.8 & 0.7 \\
\hline D & 1.4 & 1.3 & 1.2 & 1.1 & 0.9 & 0.8 & 0.7 & 0.6 \\
\hline
\end{tabular}

\section{2. 計算結果とまとめ}

まず吸着剤を均等分配した条件 Aについて，外気 温度 $45^{\circ} \mathrm{C}$ における吸着の挙動を示す.

図2の P-T 線図には多段吸着の 1 段目と 8 段目をそ れぞれ 1234，5678，従来の単段吸着を 1'2'3'4'で示し ている. それぞれの脱着作動は $2 \rightarrow 3 ， 6 \rightarrow 7 ， 2 \rightarrow 3 ’ て ゙$ あり, いずれも相対湿度が約 $\psi=0.15$ で完了する. 吸 
着作動は $4 \rightarrow 1 ， 8 \rightarrow 5,4 ’ \rightarrow$ ’であり, 多段吸着では従 来に比べ相対湿度 $\psi$ が高く有利である. また冷水の出 口側である 1 段目の蒸気圧が低く, より低温を作こと が可能である.

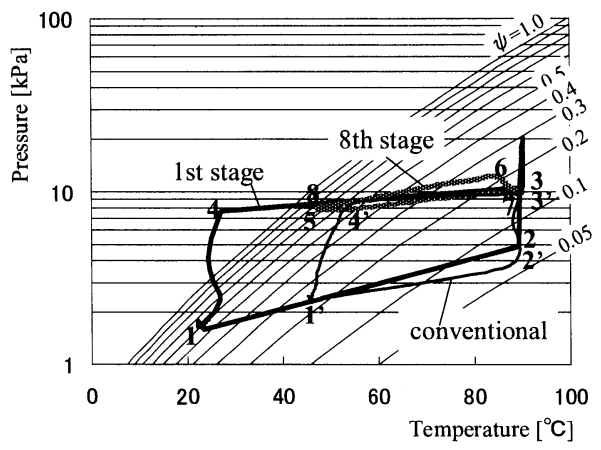

Fig. 2 The cycle in a (p-T) diagram

図 3 と 4 は吸着コアと蒸発コア(凝縮コア)内の熱交 換流体の温度変化である. $100 \mathrm{sec}$ の切替直前では $1 \sim 8$ 段まで均一な温度となり, 脱着が完了している. 吸着 時には各段で温度差を維持して作動する.

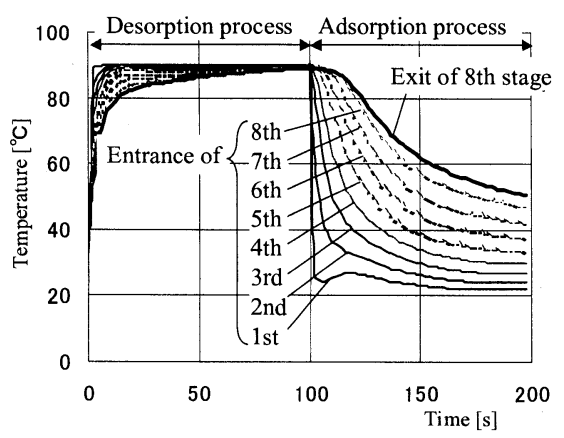

Fig. 3 Temperature profiles of fluid in adsorption core.

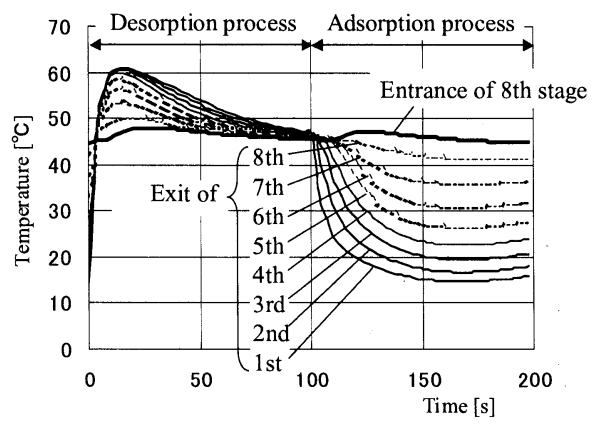

Fig. 4 Temperature profiles of fluid in condensation and evaporation core.

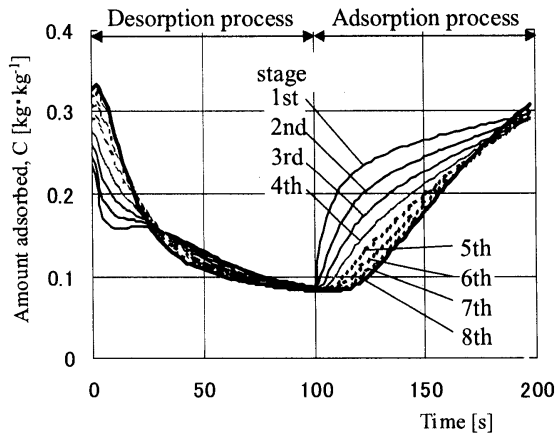

Fig. 5 Amount adsorbed profiles

図 5 は吸着剤の水分吸着率 $\mathrm{C}$ の時間変化である.低 温側（1 段目に近い）ほど初期の吸着率の増加が急峻 であり, 吸着速度が速い。これは吸着開始直後の相対 湿度 $\psi$ の差（図2の4と8の差）によるものである.

一方高温側で初期を除いてほぼ一定の増加量を示すの は，相対湿度 $\psi$ が吸着の間ほぼ一定の值（図 2 の $8 \rightarrow$ 5）を維持するからである.

このような挙動の違いから吸着剤量分配比が冷房 性能に影響を与えると考えられる.

条件 A に対する B, C, D の性能比を図 6 に示す. 低 温側の吸着剂量を傾斜的に隇らした条件 B では性能が 低下し，外気温度が高くなるほど低下割合も大きくな った. 一方, 逆に高温側の吸着剂量を傾斜的に減らし た条件 C と条件 D では性能が向上し，外気温度が高く なるほど向上割合も大きくなった. ただしCから D と した効果は目減りしている.

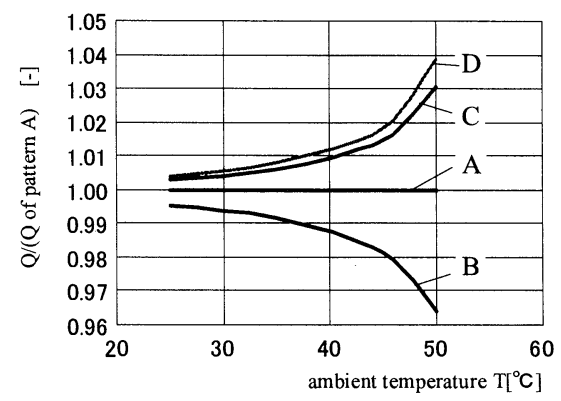

Fig. 6 Effect of adsorbent weight ratio. The cold heat output of pattem $A$ at each temperature is assumed to be unity.

以上の結果は先に述べた吸着挙動の違いによるも のと思われ，吸着の初期から中期にかけて能力の大半 を費やす低温側のほうが性能に対する寄与率が高いと 言える.よって多段吸着ではその分割を不均等にして 低温側の吸着剤量分配比を大きくしたほうが性能上有利 
である. ただし，不均等とすることで製造上の造りにく さが増すため, 均等とするか不均等とするかは性能とコ ストから選択されるべきである.

また, 本研究は高外気温時の吸着性能を確保するこ とを目的としているが，今後もシステムと材料の両面で 小型・高性能化を検討していく予定である.

\section{文献}

(1) AlamK. C. A., A. Akahira, Y. Hamamoto, A. Akisawa, T.

Kasiwagi; "A four-bed mass recovery adsorption refrigeration cycle driven by low temperature wasterrenewable heat source," Renew Energy, 29-9, 1461-1475(2004)
(2) Hamamoto Y., Alam K. C. A, A Akisawa, T. Kasiwag; "Performance evaluation of a two-stage adsorption refrigeration cycle with different mass ratio," International Journal of refrigeration, 28-3, 344-352(2005)

(3) Inoue Sa, H Mieda, Se houe, H. Sato; "Reseanch on Improvement in a Performance of an Adsorption Refrigerator," Kunkichouma Reitourengo Kouenkai, 37, 21-24(2003)

(4) Inoue Sa, Se. Inoue, N. Kobayashi; "Reseanch on Improvement in a Performance of an Adsorption Refrigerator, The Effect of Multistage Adsorption in Highly Ambient Temperature," Kikai Gakkai Ronbronshu, 72-714B, 483-490(2006) 